\title{
Uniting and Dividing Influences of Religion in Marriage Among Highly Religious Couples
}

\author{
Heather H. Kelley \\ Brigham Young University - Provo \\ Loren D. Marks \\ Brigham Young University - Provo, loren_marks@byu.edu \\ David C. Dollahite \\ Brigham Young University, david_dollahite@byu.edu
}

Follow this and additional works at: https://scholarsarchive.byu.edu/facpub

Part of the Other Social and Behavioral Sciences Commons

\section{Original Publication Citation}

Kelley, H. H., Marks,L. D., \& Dollahite, D. C. (2020). Uniting and dividing influences of religion in marriage among highly religious couples. Psychology of Religion and Spirituality, 12, 167-177.

\section{BYU ScholarsArchive Citation}

Kelley, Heather H.; Marks, Loren D.; and Dollahite, David C., "Uniting and Dividing Influences of Religion in Marriage Among Highly Religious Couples" (2019). Faculty Publications. 4825.

https://scholarsarchive.byu.edu/facpub/4825 


\title{
Uniting and Dividing Influences of Religion in Marriage Among Highly Religious Couples
}

\author{
Heather H. Kelley, Loren D. Marks, and David C. Dollahite \\ Brigham Young University
}

\begin{abstract}
Previous research has suggested that religion can be both helpful and harmful. However, much of the research on religion and families has employed relatively simple, distal measures of religion and has focused on predominantly only one side of the dualistic nature of religion. Drawing upon interviews with 198 religious couples ( $N=396$ individuals), the purpose of this study was to better understand how religion can have both a unifying and a dividing influence on marital relationships. Three overarching themes, accompanied by supporting primary qualitative data from participants, are presented. These themes include (a) how religious beliefs unite and divide marriages, (b) how religious practices unite and divide marriages, and (c) how religious communities unite and divide marriages. For the couples in this study, religion was most commonly identified as a unifying influence. However, it was also identified as having a dividing influence, including when principles were misapplied or done in excess or when ideas regarding religious beliefs, practices, and community were not shared between spouses. Implications and considerations for future research are offered.
\end{abstract}

Keywords: religion, family relationships, qualitative, marriage

Supplemental materials: http://dx.doi.org/10.1037/rel0000262.supp

Religion can be both a uniting and a dividing force in relationships. Numerous studies have shown the positive influences of religion on various relationships, but a growing body of literature also shows the negative influences of religion on those same relationships (Burr, Marks, \& Day, 2012; Marks \& Dollahite, 2017). Religion is complex and multidimensional, and it is increasingly clear that religion can be both beneficial and detrimental to relationships (Dollahite, Marks, \& Dalton, 2018; Mahoney, 2005, 2010).

One weakness of the extant empirical literature is that despite the complex nature of religion, many studies focused on the nexus of religion and family life have looked at religion from a relatively simplistic viewpoint, using only one or two measures of religiosity, often attendance and salience (Mahoney, 2010). Qualitative work can be a valuable tool to capture depth, meaning, and process (Daly, 2008; Marks \& Dollahite, 2011). Through qualitative interviews with 198 highly religious couples ( $N=396$ individuals), we have further parsed out several of the nuanced roles religion plays in unifying and dividing religious couples. Because unity in one relationship can often lead to division in other relationships, this analysis would ideally explore religion's role as a unifier and divider in relationships both within the family and outside the family. However, due to spatial constraints, the present study

This article was published Online First March 28, 2019.

Heather H. Kelley, Loren D. Marks, and David C. Dollahite, School of Family Life, Brigham Young University.

Correspondence concerning this article should be addressed to Heather H. Kelley, School of Family Life, Brigham Young University, 360 N 300 E, Provo, UT 84606. E-mail: heatherkelley@ outlook.com focuses on only marital relationships, whereas future research should address other relationships both within and outside the family.

\section{Review of Literature on the Influence of Religion in Marriage}

The theoretical foundations of this study are presented first, followed by a review of literature of religion and families addressing the role of religion in marital relationships.

\section{Theoretical Foundations}

Dollahite et al. (2018) proposed a conceptual model of a system of dualities to explain why religion is both helpful and harmful in families. One of the eight proposed dualities is that "religion in families may be relationally divisive and unifying" (p. 219). As called for by Dollahite and colleagues (2018), this article explores this dividing and uniting duality in depth. Dollahite et al. define relationally divisive as "disharmony with family members and others resulting from religious belief, identity, obligations, and choices" and relationally unifying as promoting "harmony with family members and others resulting from religious belief, practice, identity, and traditions" (p. 230). We utilize these definitions in this article; however, it is important to first further explore the word harmony, because it is not a word generally used in this body of literature. When looking at the unifying side of religion, studies have typically focused on the positive outcomes of religion on family life, such as improved marital quality and stronger parentchild relationships (Ellison, Henderson, Glenn, \& Harkrider, 2011; Wilcox, 2004). We consider harmony to encompass any of these 
positive processes and outcomes that strengthen relationships and bring individuals together. The literature surrounding the disharmony that religion creates has generally focused on struggles (Dollahite et al., 2018; Marks, Dollahite, \& Young, 2018; Exline, Pargament, Grubbs, \& Yali, 2014; Exline \& Rose, 2005) and conflict (Curtis \& Ellison, 2002). In analyzing the dividing influence of religion, we consider these constructs as well as more subtle forms of division, such as time spent apart and a sense of not belonging.

\section{Beliefs, Practices, and Community}

Dollahite et al. (2018) asserted that religion unites and divides, and previous conceptual and review work has noted at least three dimensions of religion through which such influences occur: belief, practice, and community (Dollahite, Marks, \& Goodman, 2004; Marks, 2005). Beliefs are defined as the meanings, perspectives, identities, and internal beliefs that stem from religion, whereas practices encompass more overt rituals, traditions, choices, and actions, such as church attendance and prayer, as well as acts of abstinence (e.g., fasting, abstaining from sex before marriage). Community refers to the support, involvement, obligations, and relationships that are grounded within a religious group (Dollahite et al., 2004).

Answering the call by Mahoney (2010) to look at religion through a more complex lens, these three constructs represent several distinct dimensions of religiosity, each addressing an aspect of the bio-psycho-social model (Engel, 1977; Marks, 2005). The connection between beliefs and psychological function is intuitive and has been well established. The literature shows that religious beliefs can have both positive and negative effects on psychological functioning (Ellison, Bradshaw, Flannelly, \& Galek, 2014; Huuskes, Heaven, Ciarrochi, Parker, \& Caltabiano, 2016). Specific religious practices have often been tied to various biological outcomes. For example, adherence by Seventh-day Adventists and Latter-day Saints to their respective health codes has been linked to significantly reduced death rates and cancer rates (Enstrom \& Breslow, 2008; Koenig, King, \& Carson, 2012). Additionally, more typical, outward religious practices such as prayer and church attendance have also been linked to physical outcomes such as increased longevity and reduced rates of illness (Ellison et al., 2014; Koenig et al., 2012). Community involves the social aspect of the bio-psycho-social model. For a significant portion of Americans, congregations and religious groups provide valuable social support and are the context for important relationships outside the family (Krause, 2008). Although these relationships are significant by themselves, interactions with religious communities may also have important impacts on familial relationships (Dollahite et al., 2004), as well as relationships with peers in school and work (Fiala, Bjorck, \& Gorsuch, 2002; Krause, 2011; Lazar \& Bjorck, 2008; Putnam \& Campbell, 2012) and provide a rich context for building social capital (Stark, 2012).

Just as aspects of our biology, psychology, and social interactions overlap and influence each other, there is also a good deal of overlap between beliefs, practices, and community. As such, the pairings of beliefs, practices, and community to these three constructs are imperfect and involves gray areas and overlap. Attending worship services is particularly difficult to place, because it can be both a religious practice and community interaction. For this study, when attending worship services was mentioned solely as something the couple did without mentioning the community or interactions with others, it was coded as a practice. Despite the shortcomings of this model, these three dimensions remain instructive and provide a guide to obtain a more complete picture of a complex construct.

\section{Unifying and Dividing Influence of Religion in Marriage}

Beliefs, such as the sanctity of marriage and parenting, and practices, such as prayer, have been linked to increased trust between spouses (Lambert, Fincham, LaVallee, \& Brantley, 2012) and higher levels of overall marital well-being (Ellison et al., 2011; Olson, Marshall, Goddard, \& Schramm, 2015). Religiosity can also help families reduce or overcome divisive behaviors such as marital conflict (Butler, Stout, \& Gardner, 2002; Lambert \& Dollahite, 2006; Mahoney, Pargament, Murray-Swank, \& MurraySwank, 2003), infidelity (Dollahite \& Lambert, 2007; Fincham, Lambert, \& Beach, 2010), and divorce (Brown, Orbuch, \& Bauermeister, 2008). Although religion can help to strengthen families and to reduce certain problematic issues in relationships, it can also be a major source of conflict. Religious conflict in marriage seems to stem from primarily two sources: (a) differing religious beliefs and (b) differing practices, specifically, differing levels of religious observance and involvement.

Although differing religious beliefs clearly exist in interfaith relationships (Curtis \& Ellison, 2002), they also exist in sharedfaith relationships and can lead to major conflicts (Mahoney, 2005). A scholar of interfaith marriages, Susan Miller (2013) observed that "no two individuals have identical beliefs and practices; thus, every marriage could be considered an interfaith marriage" (p. xii). The effects of these differing beliefs lie on a wide spectrum. Whereas some differences in beliefs can be benign, others can be detrimental to the relationship, often depending on the salience of the belief (Mahoney, 2005; Stokes \& Regnerus, 2009).

The ways in which religious practices are expressed within families can also lead to division among family members. One example of this is when one spouse attends worship services much more frequently than the other does. Indeed, Doherty (2000) has referred to overinvolvement in religious activities that divide spouses as "time affairs" (p. 66).

The dimension of religious communities can also have a major influence on family relationships. On the unifying side, religious communities provide important support for couples (Vaaler, Ellison, \& Powers, 2009; Wilcox, Chaves, \& Franz, 2004). However, certain types of religious demands, such as demands on time and financial donations, can be harmful and divisive for families (Dollahite et al., 2018; Curtis \& Ellison, 2002; Marks, Dollahite, \& Dew, 2009). Additionally, when family stressors occur that are not in line with the expectations of the religious community, such as divorce or childbearing outside of marriage, a faith community may exacerbate these challenges (Dollahite et al., 2004; Mahoney, 2010).

\section{Current Study}

The purpose of this study was to explore how religion may differentially influence marital relationships. In exploring the com- 
plexity inherent in religion, we look specifically at how religious beliefs, practices, and communities unify and divide marital relationships. We address these research questions through in-depth interviews with 198 couples.

\section{Method}

\section{Sample}

This study employed data from the American Families of Faith project (Marks \& Dollahite, 2017). The sample consists of 198 couples $(N=396$ individuals $)$ from the three Abrahamic faiths (Judaism, Christianity, Islam). Data collection halted when a sufficient number of couples from each of the three faiths was obtained to achieve data saturation. Participants were selected from all eight religiously diverse regions of the United States (Silk \& Walsh, 2011). Families were purposively sampled (Denzin \& Lincoln, 1994) with an intentional oversampling of racial and ethnic minorities (51\% of the sample). After obtaining Institutional Review Board approval from the researchers' university, we selected families by first contacting clergy to identify strong, marriage-based families with children who were highly committed to and involved in their faith - consistent with the "exemplar," or strengths-focused, approach of positive psychology (Damon \& Colby, 2013, p. 13). Recommended families were contacted to determine willingness to participate. Among more difficult-toaccess faiths (e.g., Islam, Orthodox Judaism), participant referral sampling (snowball sampling; see Trochim \& Donnelly, 2008, p. 49) was also employed. The final sample included 22 denominations of Abrahamic religions (for more details, see the table in the online supplemental materials). Thus, the sample is characterized by (a) a generally high level of religious commitment (as reported by referring clergy and the participants), (b) religious diversity, (c) a wide range of socioeconomic and educational levels, (d) racialethnic diversity, and (e) geographic diversity.

\section{Interview Procedure}

Each interview question was pretested to identify potential problems. Questions were open-ended, and many had follow-up questions to clarify and add depth to the initial responses. Interviews ranged from 1 to $4 \mathrm{hr}$ but typically lasted about $2 \mathrm{hr}$. Questions focused on connections between religion and family life. Interviews were transcribed verbatim and coded, as described next.

No questions were explicitly asked about the unifying or dividing influences of religion. Rather, the unifying and dividing influences of religions were identified as a common theme in the analysis of the data. That is, the idea of uniting and dividing influences emerged from analyses and is grounded in the data. However, questions were asked regarding how religion strengthened the participants' families, what role religion played in their relationships, and which religious teachings or practices were most meaningful to them. These questions elicited many of the unifying narratives. Although these questions also revealed some dividing narratives, many of the dividing narratives came from questions regarding "challenges" that the families had faced or were currently facing, as well as from a question that asked whether there were any religious beliefs or practices that, when misunderstood or misapplied, were harmful.

\section{Measures and Coding Process}

A team-based, replicable, step-by-step approach to systematically analyzing qualitative data was employed (Marks, 2015), consistent with standards of rigor recently outlined in American Psychologist (Levitt et al., 2018). Our two major analyses were performed by two different teams. Coders consisted of primarily students enrolled in a semester-long research course. In this course, coders were taught the coding process and how to use NVivo 10/11 software (QSR International, 2014). Meetings were held at least every other week to ensure interrater reliability, quality of work, and satisfactory progress.

Initial analysis. Coders involved in the primary analyses read through the transcriptions of interviews in NVivo 10 and NVivo 11 and categorized what participants said into unifying and dividing codes. Students were given a codebook to help them determine when they could categorize what a participant said as an example of the dividing or unifying nature of religion. The codebook was created following procedures described by MacQueen, McLellan, Kay, and Milstein (1998) and Bernard and Ryan (2010).

The operational definition of unites focused on connections, bonds, and relationships between individuals and others, including family members, members of their congregations, their God, and those outside their religious community. The operational definition of divides included any exclusion, separation, or criticism of others, as well as conflict with others. The initial analyses were performed by four undergraduate coders for all 198 interviews.

This initial analysis of the more than 8,000 pages of transcribed interviews took over two semesters to complete. Coders were first assigned transcripts to read and were asked to identify possible examples of religion uniting and dividing, based on the codebook. Coders were then given copies of another coder's work to read through and make note of any disagreements about unites and divides codes for purposes of establishing interrater reliability and as a "check and balance" (Marks, 2015, p. 501). Interrater reliability (calculated as the number of irresolvable differences divided by the total number of codes subtracted from 1) for data related to the core themes presented in this article was above .90 .

Secondary analysis. Our secondary analysis was completed in a two-step process. Step 1 utilized open coding to create a codebook, which was completed by the first author and one undergraduate student; consensus was needed for a theme to be identified as central. Step 2 utilized a conceptual codebook (based on themes identified through a brief review of the literature). Both of these steps used coders enrolled in a semester-long research course. Two paid research assistants also assisted. Interrater reliability for this section of coding was also above .90 .

Open coding. The first author and another research assistant open-coded the already selected accounts of unites and divides. Each were given a select number of interviews to read and identify subthemes within the accounts previously identified as "unites" or "divides." Biweekly meetings were held to discuss these ideas and come to an agreement on a codebook. Four additional coders then used this codebook to code the remaining interviews. This level of coding identified what types of relationships were being divided (e.g., marital, parental) as well as some of the causes of the unity 
or division (e.g., misunderstandings, bigotry). Not all of the themes identified at this stage appear in the article. Some will be explored in future articles.

Conceptual coding. After open coding was completed, one additional round of coding was done. Through a brief review of the literature, the first author selected several additional themes and created a codebook. Four groups of two students utilized this codebook to code all the interviews. Selected themes from the open coding from the 198 transcribed interviews were divided between the four groups of students, so that each group was responsible for analyzing a quarter of the data (about 50 interviews per coding pair). Within each pair of students, they each individually coded their assigned data. Then, coders reviewed their partner's coding and recorded any disagreements. Coders met together weekly to assess and ensure high interrater reliability (Levitt et al., 2018).

\section{Reflexivity}

Reflexivity refers to researchers' exploring and openly reporting their own assumptions, personal experiences, and other biases that may influence their research (Daly, 2008). Ideally, reflexivity also includes the effort to minimize or at least account for those biases. The three authors are active in faith communities themselves. Based on personal beliefs and experiences, as well as previous research, we were predisposed to focus on the positive outcomes of religion. However, we have also seen the divisive influence of religion in our own families and faith communities and are acutely aware that a valid story of the nexus of religion and family must attend to both complex realities (Dollahite et al., 2018; Mahoney, 2010). Additionally, in one effort to help minimize biases stemming from our personal experiences, a diverse (e.g., race, gender, age, religious backgrounds) group of students aided in completing the secondary coding analyses.

\section{Results}

Findings regarding the unifying and dividing influence of religion on marital relationships are presented in the next sections. Table 1 presents a summary of these findings, and Table 2 presents a numeric content analysis for data related to each theme, consistent with new American Psychological Association standards of both systematic rigor and transparency in qualitative research reports (Kazak, 2018; Levitt et al., 2018).

\section{Theme 1: How Religious Beliefs Unite and Divide Marital Relationships}

Theme 1, Concept A: Unifying beliefs in marital relationships. Our team coded 551 accounts, nearly three accounts per interview, as unifying beliefs in marriage. The majority of these accounts centered around beliefs specifically focused on the importance of marriage and family. These accounts included beliefs such as marriage is sacred, God is involved in their marriage, spouses are required to love and respect each other, and divorce is not an option. For example, one Christian wife stated, "Marriage is important. Marriage has got to be forever." Another Christian wife described marriage as "the vehicle that God has for taking care of each other." A Jewish husband expressed a similar idea as he
Table 1

Summary of Themes and Findings

\section{Theme 1. Religious beliefs}

1a. Unifying beliefs in marital relationships

i. Shared specific beliefs regarding the sacredness and responsibilities of marital relationships support unity.

ii. Shared beliefs create common ground between husbands and wives.

1b. Dividing beliefs in marital relationships

i. When beliefs aren't fully shared, it can create fundamental and divisive differences for couples.

ii. Differences in specific beliefs regarding gender roles and sexuality can create disunity.

Theme 2. Religious practices

2a. Unifying practices in marital relationships

i. Shared practices allow spouses to spend quality time with each other.

ii. Religious practices provide opportunities for couples to overcome differences and show their love for each other.

2b. Dividing practices in marital relationships

i. Time spent apart from each other due to religious practices can cause division.

ii. Specific gender-based practices can create division.

Theme 3. Religious community

3a. Unifying influences of community in marital relationships

i. Religious communities play an important role in union formation.

ii. Couples give and receive support.

3b. Dividing influences of community in marital relationships

i. One spouse does not feel he or she belongs in the religious community.

ii. A spouse thinks his or her partner spends too much time with the faith community.

described the Jewish belief in bashert, or soulmates, as creating wholeness in his life:

It's a concept in Judaism that your bashert is like your other half, that together you create a kind of wholeness, [a] kind of completeness. When two flames join, [they] are greater ... the [whole] is greater than the [sum of its parts].

The other accounts in this section focused on beliefs that were not specifically about marriage and family yet still had a unifying influence on the relationship. Angela, a Catholic, described how a shared belief system unified her marriage. She said, "The Gospel we chose for our wedding was 'seek first the kingdom.' I know for both [my husband] and I, that is what unites us." Brent, a Jehovah's Witness, expressed how it was his relationship with God that improved his family life, saying, "If I didn't have a good relationship with God, if that wasn't solid . . . it would have a negative impact on our family life." A Sunni Muslim wife similarly stated, "Islam has definitely blessed my marriage. . . . Our marriage has been . . . peaceful. . . . [W]ithout Islam, we would not be in [this] situation . . . Islam keeps us away from the evils of this society."

Theme 1, Concept B: Dividing beliefs in marital relationships. Our analyses identified fewer accounts regarding the dividing influence of religious beliefs within marriage. Most of the 79 accounts identified (approximately one account for every three interviews) focused on the divisive influence of spouses' having different beliefs, rather than focusing on specific beliefs that were divisive. One Jewish couple discussed the harm that resulted from having differing beliefs: 
Table 2

Numerical Content Analysis of Qualitative Coding

\begin{tabular}{|c|c|c|c|c|}
\hline Theme & $\begin{array}{l}\text { No. } \\
\text { references }\end{array}$ & $\begin{array}{l}\text { No. } \\
\text { sources }\end{array}$ & $\begin{array}{c}\% \\
\text { interviews }\end{array}$ & $\begin{array}{l}\text { Average no. references } \\
\text { per interview }\end{array}$ \\
\hline \multicolumn{5}{|l|}{ Theme 1: Religious beliefs } \\
\hline 1a. Unifying beliefs in marital relationships & 551 & 146 & 73.7 & 2.8 \\
\hline 1b. Dividing beliefs in marital relationships & 79 & 59 & 31.2 & .4 \\
\hline \multicolumn{5}{|l|}{ Theme 2: Religious practices } \\
\hline 2a. Unifying practices in marital relationships & 606 & 146 & 73.7 & 3.1 \\
\hline 2b. Dividing practices in marital relationships & 92 & 59 & 29.8 & .5 \\
\hline \multicolumn{5}{|l|}{ Theme 3: Religious community } \\
\hline 3a. Unifying influences of community in marital relationships & 74 & 51 & 25.8 & .4 \\
\hline 3b. Dividing influences of community in marital relationships & 20 & 19 & 9.6 & .1 \\
\hline Total & 1,330 & 198 & 100 & 6.7 \\
\hline
\end{tabular}

Eli: I came from . . . well, let's say that it was a [hyper]critical background, that the things which I [was taught] made it even harder for me to accept things later.

Hannah: You didn't think they could really [be] valid.

Eli: Right, a certain validity. It took me many years, many years in fact. It's only pretty recently that we find ourselves close to being in the same place, in terms of acceptance ... and that caused marriage stress. There were disagreements, foot-dragging.

For Eli and Hannah, as with most of the accounts in the section, division in their marriage resulted from their not sharing the same beliefs or interpreting and emphasizing certain beliefs differently. However, some couples reported that certain specific beliefs led to disunity within their marriages. The only recurring specific beliefs that were identified as having a dividing influence were beliefs regarding sexuality and gender roles. George, a Lutheran, expressed how the beliefs regarding sexuality he gained from his religious upbringing in a different Christian denomination were harmful to his marriage:

All the parochial education, unfortunately, I think, has had a negative effect on me . . because I think that it totally ruins my whole idea of sexuality. Which I think is an important part of a marriage, and can be a spiritual thing, and I think that the education that I got in a Catholic tradition was to just ignore that and have a shame about it, and I think it has hurt our marriage.

Whereas George shared a personal narrative of how his religious education regarding sexuality had a divisive impact on his marriage, many of the accounts regarding the divisive potential or influence of these beliefs were nonpersonal or hypothetical. For example, one Jewish husband said,

Not in our marriage, but in other marriages, people who are very religious, who are Jewish, have a very chauvinistic, or very unbalanced, view on what's the male role and what female roles are in life and in marriage, and I could see that, if we were to follow that path, I would be really unhappy, and that would cause a lot of strife in this family.

Whether participants had not experienced the divisive influence of these beliefs firsthand or whether they were not comfortable sharing personal experiences regarding how religion had been divisive in their relationships, this trend contrasted with many of the personal unifying accounts that were identified. It is also worth noting the past tense used in the first account and others in this section. From the first account, it appears that Eli and Hannah have been able to work through much of the problems and division that religious beliefs had created for their marriage. Although there was a mixing of present and past tense in both the unifying and dividing religious belief accounts, the use of the past tense appeared to be more prevalent among the dividing accounts. This may be because it is easier to talk about past challenges than current challenges.

As seen in the previous narratives, for many, religious beliefs compose a fundamental part of their identity. These beliefs can be unifying when shared, because they create a shared identity, but can also be divisive when family members do not share the same beliefs-or have sharply different, even conflicting beliefs. The next section explores how religious practices can similarly have both a unifying and dividing influence on marital relationships.

\section{Theme 2: How Religious Practices Unite and Divide Marital Relationships}

Religious practices generally had a unifying influence when they were done together, and thus resulted in time spent together, and had a dividing influence when they were done individually, and thus resulted in time spent apart. Examples of this, along with other ways religious practices both unified and divided our sample's marital relationships, are presented in this section.

Theme 2, Concept A: Unifying practices in marital relationships. Our analyses yielded 606 accounts (approximately three accounts per interview) of unifying practices within marriage. Many of these unifying accounts were about how religious practices created a reason for couples to spend time together. Ibrahim, a Sunni Muslim husband, described his experience doing the Hajj, the pilgrimage to Mecca, by saying, "It was such a great spiritual experience, and in Hajj, the husband and wife do everything together. You hold hands and you do all of the things together." For Vera, an Asian Christian, it was weekly church attendance that reportedly created time for her to spend with just her husband:

On Sundays, I feel that [familial] closeness more than I do on other days of the week [when] we're just going through the motions and things are so busy. . . . Sunday is a family day and a day to worship ... and when we would go to [church, our children] would be in 
Sunday school and ... nursery, so it's just [my husband] and I. So that's a very special time for me. We hold hands in church.

Similarly, Hannah described her experience observing the Jewish practice of Shabbat as follows:

Six days a week you have to work for a living, but you have this one day you do not have to; you cannot. You have to spend all of your time praying, all of your time with your family, all of your time visiting with God, so to speak. That's very refreshing.

Whereas these previous accounts reflect practices that brought couples together for longer periods of time occasionally, other accounts described practices that occurred more regularly (usually daily or twice daily) and brought the couples together for shorter periods of time. These practices included daily scripture study and prayer. Prayer appeared to be the most common practice couples did together on a regular basis. For example, Anne, an Orthodox Christian wife, stated, "[My husband] and I say prayers as a couple, and we try to do that every night." Mason, a member of the Church of Jesus Christ of Latter-day Saints, similarly said:

We have companionship prayer every night, and that's pretty good. [We] made a little promise to each other when we were first married that we would never go to bed angry with one another or unresolved, and we've knelt at the bedside till [we're no longer angry with each other].

This previous account shows how religious practices not only created unity among the couples in our sample by encouraging them to spend time together on a regular basis but also helped unify couples by making the time spent together meaningful. By setting aside time to pray together every night, Mason and his wife were able to overcome their daily differences and issues and thus were also able to prevent problems and differences from festering. Ruby, a Methodist, similarly expressed how prayer helped her overcome conflict with her husband; however, prayer in this instance was an individual practice, rather than a practice that was done as a couple. Ruby said, "[My husband will] usually go to bed in the conflict and I'm up, all night, and then finally realize, I'll go to God. He'll help me through this." For a Jewish couple, Abe and Dalia, it was studying the Torah that helped them to overcome some of their challenges:

My husband and I study together; and that's been really important. Sometimes, especially [with a] complicated family life with stepkids and teenagers ... things will get brought down ... just one stress or whatever after another. To have [the Torah] as a constant presence in the house, and studying Torah, it really kind of changes the environment.

Religious practices were not only described as useful in overcoming challenges; many of the couples in our sample also described how these practices strengthened or enriched their relationships and their lives. A Latter-day Saint wife expressed this, saying, "We have our couple prayer together whenever we can. Besides the strength you draw from those experiences . . . hearing your spouse pray for you is really humbling." Briana and Ted, a Christian couple, similarly discussed how religious practices strengthened them both individually and as a couple:

Briana: I think the personal, family, and marital benefits for us is that we grow together in God. We study to- gether, we pray together, we fellowship together, and being under [the] pastor and first lady that we are under, they're able to pour into us. So, that's a good benefit for me, you know, serving God together as husband and wife, loving God together.

Ted: $\quad$ And it makes your marriage strong when you pray together and stay together, because when you have challenges and downfalls, you lift one another up. Where one is weak, the other is strong . . you can lift each other up at the same time.

Theme 2, Concept B: Dividing practices in marital relationships. Although our participants reported many such benefits and unifying influences on their marriages as resulting from religious practices, they also reported on the dividing influence of religious practices on their marriages; however, there were again far fewer dividing accounts than unifying accounts. As with unifying practices, many of the 92 accounts (nearly one for every two interviews) of dividing practices dealt with time. The dividing influence of religious practices on marital relationships in relation to time varied greatly. For some, some practices simply took time away from their marriage but were not necessarily viewed as problematic. These accounts generally consisted of practices that were done individually, such as Muslim men going to the mosque or Jewish men going to the synagogue without their wives. For Jennifer and her husband, who were Jehovah's Witnesses, it was missionary work that interfered with their time as a couple. Jennifer stated:

When [our daughter] was out of school, I joined this missionary type program, and when [my husband] retired, instead of stopping that to spend more time with him, I have continued doing that, and [he's] in a position where it would be nicer if I could be home more. But [he has] chosen to kind of make that sacrifice because I'm still really enjoying this, and [he supports] it when [he] can, but it's . . . a little thing we've worked out.

Although it was a sacrifice for Jennifer's husband, they were able to come to a mutual agreement on how much time she spent involved in missionary work and were thus able to reduce the divisive influence of religious practices on their relationship. Several other couples related similar experiences where they struggled to find a proper balance between religious practices and family time. For some, including the following Lutheran couple, this was a recurring process, which the wife described:

We struggle sometimes with being overcommitted in the church, where we're spending more time there or devoting our time there rather than to each other and home life at times. Fortunately, we catch it, and we usually correct it fairly quickly, but we find ourselves getting so wrapped up into that.

Whereas these previous accounts described religious time commitments as challenging but manageable, for others, time commitments related to religious practices presented a major issue for the couple and thus were perceived as quite divisive. As one Evangelical wife recounted, "When [my husband] was a deacon, he got enthusiastic about our church . . . and he went all the time. . . . Some of our biggest fights have been about our church."

Beyond the dividing influences of time apart for religious practices, the only specific and recurring practices that were identified 
as being divisive dealt with gender and sexuality. This reflects the pattern that emerged in divisive religious beliefs, and as with divisive beliefs, many of these accounts were nonpersonal or hypothetical. This can be seen in the following account from Stuart, a Latter-day Saint husband:

We have what we call the priesthood, [which] is the men hold a calling where they are serving in the Savior's place, as if the Savior were here. They're to serve other people. But I think sometimes men in the church will use that calling as a superiority issue, and when it's done in a marriage relationship, it can be very harmful, and they can use that as an excuse to get what they want or to treat their wife poorly.

As reflected in this account and others in the data, the practice itself was not divisive, but how individuals interpreted and applied the practice could cause it to become divisive and harmful in marriages. Indeed, some couples did report that gender roles had a unifying influence on their marriages. In response to the question "Do you feel like there are any religious beliefs or practices that if misunderstood or misapplied can be harmful to marriage?" Efrem, a Jewish husband, described how it is not the practice itself that is divisive but, rather, how the couple chooses to implement and live certain practices that can be harmful:

I think the thing that would be the most dangerous to a relationship might be any sort of dogma that you would bring to it, not the thing itself. If you begin to practice something and ... developed a negative view of me because I didn't . . that's not about the practice itself. It's about us.

This idea was illustrated in several accounts, including a conversation between a Jewish couple, Simon and Talia. After discussing how they had seen gender roles be divisive in Talia's Christian siblings' marriages, Simon recounted how similar gender roles helped promote equality in their marriage:

In the Jewish religion, the woman is in charge of the house. That's . . . standard. . . . The man makes money. It's more of an equal relationship, and the woman runs the house. [If] she says, "I want to paint this purple," [then] I say, "It's going to be painted purple." I have no say so in it ... [only] indirectly, maybe, ... but she runs the house. I think from that standpoint, from the Jewish standpoint, I think [it] is more of an equal thing than the Christians that are the born-again types.... I think in the Jewish religion it's more equal.

As illustrated by these previous accounts, similar practices can be applied and perceived differently, and the application and perception of that practice appeared to be a better determiner of whether it would have a unifying or dividing influence than the practice itself did.

\section{Theme 3: How Religious Communities Unite and Divide Marital Relationships}

Overall, there were far fewer accounts identified regarding the unifying or dividing influence of religious communities on family relationships. Despite the fact that these accounts were less prevalent than were the accounts identified as unifying or dividing beliefs and practices, community still played a salient role in familial relationships for many of our participants.

According to our analyses, community had a primarily unifying influence on marital relationships and rarely had a reportedly divisive influence. This is in part due to the coding criteria that was used. Because there can be a good deal of conceptual overlap between some religious practices and community, these two constructs were distinguished in the analyses as follows: Any practices related to the religious community, such as attending worship services and teaching Sunday school, were coded under religious practices rather than community. Time spent beyond regular practices, or any service given to or received from the members of the religious community, was coded under community.

Theme 3, Concept A: Unifying influences of community in marital relationships. Our team-based coding identified 74 accounts (nearly one per three interviews) regarding the unifying influence of religious communities on marital relationships. These accounts focused primarily on the support that the couples received from their religious communities, whether it was physical, emotional, or spiritual. Several couples mentioned how important this support was specifically in the formation of their marriage, as illustrated in the following account from a Christian wife:

[Marriage] allows there to be trust . . . it gives you the support of the community, and if you do it in the faith context, like we did it in a church, you know, before God and all the assembled family and friends, that supports that trusting, committed bond.

For Susan and Mitch, getting married in their church had a powerful and even transformative influence on their marriage. Susan recalled:

For a long time, [my husband] and I were of a mind, like, [why] does [marriage] matter? . . . I know he loves me and he knows I love him, and we vowed to take care of each other and love each other. Why should we do this whole marriage thing? ... [but] then we [got] to the church and that act ... of getting married, of being in the church and having all of these people here to witness, and to be part of that union, and to have God part of that union. And the two of us were really of [the same] mind, when we left ... We had no idea it was going to be like this. It was so different than what we had imagined. It was so incredibly powerful.

Susan expressed how those present became a part of their marriage, alluding to the continued influence of their religious community in their marriage. The support couples gained from their religious communities throughout their marriages was also common throughout this section. Sophie, a Presbyterian wife, expressed how her religious community helped her and her husband through tough times in their marriage.

I do not feel alone. I have the faith community. We have practices that are kind of comforting, I would say. There's something to hold onto in terms of practicing your faith together as a group. I value that experience, and that's helpful when [we're] going through tough times, whatever they might be in [our] marriage.

Some couples expressed how service in their community was reciprocal, how they both gave and received service. Just as the support of members of the religious community had a unifying influence on marriages and families, supporting others in the community was also identified as a unifying experience. A Catholic couple described this as follows:

Kathy: In marriage ... we do all the faith stuff. But, the faith system of the community, our faith has been beneficial for us, as far as having other families ... 
Kurt: It's a community of people who, you know, get together and all bake [pasta] for each other at different occasions or celebrations . . . You celebrate together, and when someone dies, you're there together. When you need a helping hand, [they're] there. And when someone else is sick, you're cooking them a meal, and that becomes the fabric of your existence in the town and the community, so that becomes really important.

As illustrated by this previous account, it was often the small acts of service (such as baking pasta or being there to both celebrate the achievements and mourn the losses of others) that had a unifying influence. However, when time commitments and sacrifices for the religious communities interfered with family life, they could have a divisive influence.

Theme 3, Concept B: Dividing influences of community in marital relationships. There were only 20 accounts (one account per 10 interviews) coded regarding the divisive influence of community within marriages. A few of the accounts in this section dealt with one of the spouses' feeling like he or she didn't belong in the religious community. One Jewish convert, Tailia, described how religion that been a problem for them in the past, including the follow account of how her Christian religious community impacted her husband when they were dating, saying,

He would go to church with me, and then after church, he would look at me and he would say, "Do you know that they prayed for everybody in that church except me?" And I said, "What are you talking about?" And he said, "They would say, 'Let's bow our heads and pray for our Christian brothers and sisters." "He said, "And I'm not Christian, so they're not praying for me."

Despite the problems that a sense of not belonging could bring, most of the accounts dealt with the time that serving and interacting with community members took away from time as a couple or from their ability to support each other. One Latter-day Saint wife described how easy it was to become overinvolved in serving the members of their religious community, saying,

We are so committed [to serving] in this church. . . . We dedicate our lives and a lot of time and effort into programs in the church, helping the youth with camp, helping primary with, you know, learning new songs, teaching lessons, and I think that can be taken to an extreme to where you can neglect your family.

Thomas, an Evangelical Christian, similarly reflected on the challenges serving in the ministry created for his wife in the past, saying, "I wound up . . . leaving the ministry because we just saw I was away from home 60-80 [hours] a week and she felt like a widow many times, especially with our only child.” Joelle, a Black Christian, reported a nonpersonal experience, recounting the challenges some of the women in her Bible study group faced in their marriages:

There were other women in this group whose husbands were just fighting it. They were just fighting it, you know. I'm going, "Why would you fight your wife becoming more Godly?" I'm confused. I couldn't understand why a sensible man would fight this. You know, to become more good. . . . She's hanging out with other women, not men, studying the Bible.
It is important to note here that these dividing accounts occurred when husbands or wives served or met with members of their religious community individually. As previously mentioned, when husbands and wives spent time serving and interacting with those in their community together, it often appeared to have a unifying influence on their relationship. This idea was succinctly expressed by Feng, an Asian Christian, who said, "Satan tempts us. . . . You can imagine if I want to go to church and she wants to go outside shopping, . . . but once we are both involved in church, that actually makes us happy."

\section{Discussion}

Through qualitative analyses of 198 interviews with highly religious couples, this study identified ways religion can have both a unifying and dividing influence on marital relationships. This study illustrates how religion is often a tool, rather than a force in and of itself. Although some beliefs and practices tend to have a more unifying or dividing influence than others, these findings suggest that the most important factor is how the beliefs and practices are applied, rather than what they are. In doing this, the study simultaneously provided examples of how religion has been applied both in a unifying manner and in a dividing manner. For example, the data showed that beliefs and practices regarding gender and sexuality were prone to having a more divisive influence than most other beliefs and practices did. However, for some, gender roles and teachings about sexuality did have a unifying influence on their marriage.

It is important to note that dividing influences may not always be inherently negative, and even when religion does have a divisive influence that appears negative for that relationship, this does not necessarily mean it will be negative in the long run. Throughout our analysis of dividing beliefs, practices, and community influences, many of the accounts identified were described in past tense. If these challenges can be effectively overcome, perhaps they can strengthen the relationships and lead to greater unity. The model presented by Dollahite et al. (2018, p. 234) lists unifying influences as "stabilizing" and dividing influences as "dynamic," and calls for finding a balance and flux between the two. The resulting tension between spouses when beliefs, practices, and community involvement vary may play an important role in creating opportunities for spouses to change, develop, and better understand the religion they share. Future research should investigate this.

Future research should also extend beyond marital relationships to investigate whether division in one relationship may result in increased unity in a different relationship. For example, this analysis identified that religion had a dividing influence on spouses when there were differences between each spouse's individual religious beliefs. Division between spouses in this instance may be accompanied by greater unity in their relationships with likeminded peers. However, because the focus of this article was limited to an analysis of the marital relationship, this was not explored. Future research could build from this study and employ quantitative methods to examine the unifying influence of religion in certain relationships and its dividing influence in other relationships.

Across beliefs, practices, and community, far more unifying accounts were identified than were dividing accounts (approxi- 
mately 3-7 times more unifying accounts were identified across the three themes). Although this is likely due in part to the fact that the sample consisted of religious families who had strong marriages, it is also likely due in part to the nature and purposes of religion. Across Abrahamic faiths, family is important. Christianity, Judaism, and Islam all have the sanctity of marriage among their fundamental doctrines (Agius \& Chircop, 1998). As illustrated by the high number of unifying accounts, it appears that these doctrines on marriage do seem to have a tangible influence on couples. However, even among the highly religious, these teachings may still have a dividing influence.

Another finding is that the unifying and dividing influences of beliefs and practices on marital relationships were more prevalent than the unifying and dividing influence of community on these relationships were. Although community did still play an important role in relationships, it appears practices and beliefs that were done individually and as a couple may have been more influential for most couples' relationships than their interactions with members in their religious communities have.

Additionally, among the various religious practices that can help unify couples, prayer appeared to be the most common practice. Unlike most practices, which were generally done either privately or as a couple, prayer was regularly done both privately and as a couple. Additionally, although this study did not identify prayer as having a dividing influence on relationships, it is important to note that some studies have identified prayer as having a negative and harmful influence, particularly when it is used to criticize or manipulate (Lambert et al., 2012). The lack of accounts regarding the divisive influence of prayer in this study is likely due in part to the fact that these were exemplary couples. Future research regarding prayer and relationships should intentionally seek to understand both the benefits and costs of prayer, as should much of the future research on religion, as discussed next.

\section{A Model for Future Research on Religion and Relationships}

In addition to the findings and implications discussed thus far, this article also presents a compelling model by which religion and family life may be studied. For many years, religion has been viewed as either predominantly negative or predominantly positive (Marks \& Dollahite, 2017). Up until the 1970s, religion was often viewed as a mainly negative influence. Between prominent scholars like Freud's referring to religion as a "poison" (Freud, 1927, p. 88 ) and the many negative references of religion in the third edition of the Diagnostic and Statistical Manual of Mental Disorders (American Psychiatric Association, 1980), religion was largely viewed as pathology. However, in 1971, Rodney Stark published a study that showed an inverse relationship between religion and mental illness, showing that contrary to the general opinion on religion in psychology, religiosity was associated with a lower incidence of psychopathy (Stark, 1971). Stark and others continued to apply high-quality methods to the study of religion and health that ultimately helped overturn the stigma of religion as psychopathy (e.g., Bergin, 1991; Stark \& Finke, 2000). As studies continued to demonstrate the many positive outcomes of religion on both individuals and relationships, some scholars in the fields of psychology and family studies began to view religion as a largely positive force (see Marks \& Dollahite, 2017).
In recent years, a more nuanced view of how religion is both helpful and harmful in relationships has emerged in the field (Burr et al., 2012; Dollahite et al., 2018; Mahoney, 2010). However, many of the studies that do address the dualistic nature of religion often focus primarily on one side (generally the positive side) and only briefly address the opposing side in the discussion or as a peripheral finding. Another weakness of the extant literature is that in large part, studies dealing with religion have used simplistic measures of religion, such as a single measure of attendance or salience (Mahoney, 2010). By applying a bio-psycho-social model and through looking at the three religious dimensions of practices, beliefs, and community, this study provides a more holistic picture of some of the ways religion can be both a unifying and dividing influence in familial relationships. By looking at multiple dimensions of religion and by intentionally seeking to understand both the positive and negative influences of religion simultaneously, this study may provide a model that future studies can employ in the study of religion and family.

\section{Limitations}

Although the sample had many strengths, including its large size of 198 couples ( $N=396$ individuals) and its racial, religious, and geographic diversity, it was not without limitations. First, our sample included only religious, intrafaith couples from Abrahamic faiths. Future research should investigate the unifying and dividing influence of religion on interfaith couples, couples who are both moderately and marginally religious, and faiths outside the Abrahamic tradition. Additionally, as mentioned briefly earlier, this study investigated religion's unifying and dividing influence on only marital relationships. To better understand the implications of the unifying and dividing nature of religion, other relationships should be investigated as well.

\section{Conclusion}

For the couples in this study, religion reportedly had both a unifying and a dividing influence on their marital relationships. Although religion was most commonly identified as a unifying influence, it was also identified as having a dividing influence at times, particularly when principles were misapplied or done in excess, or when ideas regarding religious beliefs, practices, and community were not shared within a marriage. Additionally, this study provided a model by which future studies can approach the complexity inherent in the nexus of religion and relationships. As scholarship on how religion influences marriage and family relationships becomes more conceptually balanced and sophisticated, the field will be better able to provide evidence-based best practices to those who work with religious families.

\section{References}

Agius, E., \& Chircop, L. (Eds.). (1998). Caring for future generations: Jewish, Christian and Islamic perspectives. Westport, CT: ABC-CLIO. American Psychiatric Association. (1980). Diagnostic and statistical manual of mental disorders (3rd ed.). Washington, DC: Author.

Bergin, A. E. (1991). Values and religious issues in psychotherapy and mental health. American Psychologist, 46, 394-403. http://dx.doi.org/ 10.1037/0003-066X.46.4.394 
Bernard, H. R., \& Ryan, G. W. (2010). Analyzing qualitative data. Los Angeles, CA: Sage.

Brown, E., Orbuch, T. L., \& Bauermeister, J. A. (2008). Religiosity and marital stability among Black American and White American couples. Family Relations, 57, 186-197. http://dx.doi.org/10.1111/j.1741-3729 .2008.00493.x

Burr, W. R., Marks, L. D., \& Day, R. (2012). Sacred matters. New York, NY: Routledge. http://dx.doi.org/10.4324/9780203641323

Butler, M. H., Stout, J. A., \& Gardner, B. C. (2002). Prayer as a conflict resolution ritual. American Journal of Family Therapy, 30, 19-37. http://dx.doi.org/10.1080/019261802753455624

Curtis, K. T., \& Ellison, C. G. (2002). Religious heterogamy and marital conflict: Findings from the National Survey of Families and Households. Journal of Family Issues, 23, 551-576. http://dx.doi.org/10.1177/01925 13X02023004005

Daly, K. (2008). Qualitative methods for family studies and human development. Thousand Oaks, CA: Sage.

Damon, W., \& Colby, A. (2013). Why a true account of human development requires exemplar research. New Directions for Child and Adolescent Development, 2013, 13-25. http://dx.doi.org/10.1002/cad.20046

Denzin, N. K., \& Lincoln, Y. S. (Eds.). (1994). Handbook of qualitative research. Thousand Oaks, CA: Sage.

Doherty, W. J. (2000). Take back your marriage. New York, NY: Guilford Press.

Dollahite, D. C., \& Lambert, N. M. (2007). Forsaking all others: How religious involvement promotes marital fidelity in Christian, Jewish, and Muslim couples. Review of Religious Research, 48, 290-307. http://dx .doi.org/10.1300/J002v38n01_07

Dollahite, D. C., Marks, L. D., \& Dalton, H. (2018). Why religion helps and harms families: A conceptual model of a system of dualities at the nexus of faith and family life. Journal of Family Theory \& Review, 10, 219-241. http://dx.doi.org/10.1111/jftr.12242

Dollahite, D. C., Marks, L. D., \& Goodman, M. A. (2004). Families and religious beliefs, practices, and communities. In M. Coleman \& L. Ganong (Eds.), Handbook of contemporary families (pp. 411-431). Thousand Oaks, CA: Sage.

Ellison, C., Bradshaw, M., Flannelly, K., \& Galek, K. (2014). Prayer, attachment to God, and symptoms of anxiety-related disorders among U.S. adults. Sociology of Religion, 75, 208-233. http://dx.doi.org/10.1093/socrel/srt079

Ellison, C. G., Henderson, A. K., Glenn, N. D., \& Harkrider, K. E. (2011). Sanctification, stress, and marital quality. Family Relations, 60, 404420. http://dx.doi.org/10.1111/j.1741-3729.2011.00658.x

Engel, G. L. (1977, April 8). The need for a new medical model: A challenge for biomedicine. Science, 196, 129-136. http://dx.doi.org/10.1126/science .847460

Enstrom, J. E., \& Breslow, L. (2008). Lifestyle and reduced mortality among active California Mormons, 1980-2004. Preventive Medicine, 46, 133-136. http://dx.doi.org/10.1016/j.ypmed.2007.07.030

Exline, J. J., Pargament, K. I., Grubbs, J. B., \& Yali, A. M. (2014). The Religious and Spiritual Struggles Scale. Psychology of Religion and Spirituality, 6, 208-222. http://dx.doi.org/10.1037/a0036465

Exline, J. J., \& Rose, E. (2005). Religious and spiritual struggles. In R. F. Paloutzian \& C. L. Park (Eds.), Handbook of the psychology of religion and spirituality (2nd ed., pp. 380-398). New York, NY: Guilford Press.

Fiala, W. E., Bjorck, J. P., \& Gorsuch, R. (2002). The Religious Support Scale: Construction, validation, and cross-validation. American Journal of Community Psychology, 30, 761-786. http://dx.doi.org/10.1023/A: 1020264718397

Fincham, F. D., Lambert, N. M., \& Beach, S. R. (2010). Faith and unfaithfulness: Can praying for your partner reduce infidelity? Journal of Personality and Social Psychology, 99, 649-659. http://dx.doi.org/ 10.1037/a0019628

Freud, S. (1927). The future of an illusion. Garden City, NY: Doubleday.
Huuskes, L. M., Heaven, P. L., Ciarrochi, J., Parker, P., \& Caltabiano, N. (2016). Is belief in God related to differences in adolescents' psychological functioning? Journal for the Scientific Study of Religion, 55, 40-53. http://dx.doi.org/10.1111/jssr.12249

Kazak, A. E. (2018). Editorial: Journal article reporting standards. American Psychologist, 73, 1-2. http://dx.doi.org/10.1037/amp0000263

Koenig, H. G., King, D., \& Carson, V. B. (2012). Handbook of religion and health (2nd ed.). New York, NY: Oxford University Press.

Krause, N. (2008). Aging in the church. West Conshohocken, PA: Templeton Foundation Press.

Krause, N. (2011). Do church-based social relationships influence social relationships in the secular world? Mental Health, Religion \& Culture, 14, 877-897. http://dx.doi.org/10.1080/13674676.2010.534775

Lambert, N. M., \& Dollahite, D. C. (2006). How religiosity helps couples prevent, resolve, and overcome marital conflict. Family Relations, 55, 439-449. http://dx.doi.org/10.1111/j.1741-3729.2006.00413.x

Lambert, N. M., Fincham, F. D., LaVallee, D. C., \& Brantley, C. W. (2012). Praying together and staying together: Couple prayer and trust. Psychology of Religion and Spirituality, 4, 1-9. http://dx.doi.org/10.1037/a0023060

Lazar, A., \& Bjorck, J. P. (2008). Religious support and psychosocial well-being among a religious Jewish population. Mental Health, Religion \& Culture, 11, 403-421. http://dx.doi.org/10.1080/136746707 01486142

Levitt, H. M., Bamberg, M., Creswell, J. W., Frost, D. M., Josselson, R., \& Suárez-Orozco, C. (2018). Journal article reporting standards for qualitative primary, qualitative meta-analytic, and mixed methods research in psychology: The APA Publications and Communications Board task force report. American Psychologist, 73, 26-46. http://dx .doi.org/10.1037/amp0000151

MacQueen, K., McLellan, E., Kay, K., \& Milstein, B. (1998). Codebook development for team-based qualitative analysis. Cultural Anthropology Methods, 10, 31-36.

Mahoney, A. (2005). Religion and conflict in marital and parent-child relationships. Journal of Social Issues, 61, 689-706. http://dx.doi.org/ 10.1111/j.1540-4560.2005.00427.x

Mahoney, A. (2010). Religion in families 1999 to 2009: A relational spirituality framework. Journal of Marriage and Family, 72, 805-827. http://dx.doi.org/10.1111/j.1741-3737.2010.00732.x

Mahoney, A., Pargament, K. I., Murray-Swank, A., \& Murray-Swank, N. (2003). Religion and the sanctification of family relationships. Review of Religious Research, 44, 220-236. http://dx.doi.org/10.2307/3512384

Marks, L. (2005). Religion and bio-psycho-social health: A review and conceptual model. Journal of Religion and Health, 44, 173-186. http:// dx.doi.org/10.1007/s10943-005-2775-z

Marks, L. D. (2015). A pragmatic, step-by-step guide for qualitative methods. Current Psychology, 34, 494-505. http://dx.doi.org/10.1007/ s12144-015-9342-x

Marks, L. D., \& Dollahite, D. C. (2011). Mining the meanings and pulling out the processes from psychology of religion's correlation mountain. Psychology of Religion and Spirituality, 3, 181-193. http://dx.doi.org/10.1037/ a0022206

Marks, L. D., \& Dollahite, D. C. (2017). Religion and families: An introduction. New York: Routledge/Taylor \& Francis.

Marks, L. D., Dollahite, D. C., \& Dew, J. (2009). Enhancing cultural competence in financial counseling and planning: Understanding why families make religious contributions. Journal of Financial Counseling and Planning, 20, 14-26.

Marks, L. D., Dollahite, D. C., \& Young, K. P. (2018). Struggles experienced by religious minority families in the United States. Psychology of Religion and Spirituality. Advance online publication. http://dx.doi.org/ 10.1037/rel0000214

Miller, S. (2013). Being both: Embracing two religions in one interfaith family. Boston, MA: Beacon. 
Olson, J., Marshall, J., Goddard, H. W., \& Schramm, D. (2015). Shared religious beliefs, prayer, and forgiveness as predictors of marital satisfaction. Family Relations, 64, 519-533. http://dx.doi.org/10.1111/fare .12129

Putnam, R. D., \& Campbell, D. E. (2012). American grace: How religion divides and unites us. New York, NY: Simon \& Schuster.

QSR International. (2014). NVivo qualitative data analysis Software; QSR International Pvt. Ltd. (Version 11, 2014) [Computer software]. Retreived from https://www.qsrinternational.com/nvivo

Silk, M., \& Walsh, A. (2011). One nation, divisible: How regional religious difference shape American politics (Vol. 9). Lanham, MD: Rowman \& Littlefield.

Stark, R. (1971). Psychopathology and religious commitment. Review of Religious Research, 12, 165-176. http://dx.doi.org/10.2307/3510420

Stark, R. (2012). America's blessings: How religion benefits everyone, including atheists. West Conshohocken, PA: Templeton Foundation Press.

Stark, R., \& Finke, R. (2000). Acts of faith: Explaining the human side of religion. Berkeley: University of California Press.
Stokes, C. E., \& Regnerus, M. D. (2009). When faith divides family: Religious discord and adolescent reports of parent-child relations. Social Science Research, 38, 155-167. http://dx.doi.org/10.1016/j.ssresearch.2008.05.002

Trochim, W. M. K., \& Donnelly, J. P. (2008). The research methods knowledge base (3rd ed.). Mason, OH: Cengage.

Vaaler, M. L., Ellison, C. G., \& Powers, D. A. (2009). Religious influences on the risk of marital dissolution. Journal of Marriage and Family, 71, 917-934. http://dx.doi.org/10.1111/j.1741-3737.2009.00644.x

Wilcox, W. B. (2004). Soft patriarchs, new men. Chicago, IL: University of Chicago Press.

Wilcox, W. B., Chaves, M., \& Franz, D. (2004). Focused on the family? Religious traditions, family discourse, and pastoral practice. Journal for the Scientific Study of Religion, 43, 491-504. http://dx.doi.org/10.1111/ j.1468-5906.2004.00251.x

Received June 21, 2018

Revision received December 21, 2018 Accepted February 12, 2019 